\title{
Mass Mobilization and the Durability of New Democracies
}

\author{
Mohammad Ali Kadivar \\ Brown University
}

Corresponding Author: Mohammad Ali Kadivar

Watson Institute for International and Public Affairs, 111 Thayer St, Providence, RI 02912.

Email: kadivar@brown.edu

\begin{abstract}
The "elitist approach" to democratization contends that "democratic regimes that last have seldom, if ever, been instituted by mass popular actors" (Huntington 1984:212). This article subjects this observation to empirical scrutiny using statistical analyses of new democracies over the past half-century and a case study. Contrary to the elitist approach, I argue that new democracies growing out of mass mobilization are more likely to survive than are new democracies that were born amid quiescence. Survival analysis of 112 young democracies in 80 different countries based on original data shows that the longer the mobilization, the more likely the ensuing democracy is to survive. I use a case study of South Africa to investigate the mechanisms. I argue that sustained unarmed uprisings have generated the longest-lasting new democracies- largely because they are forced to develop an organizational structure, which provides a leadership cadre for the new regime, forges links between the government and society, and strengthens checks on the power of the post-transition government.
\end{abstract}

\section{Keywords}

Social Movements, Democratization, Mobilization, Organization

The literature on democratic survival rarely takes account of social movements; instead, it focuses primarily on economic, institutional, and international factors (Kapstein and Converse 2008). The literature on social movement outcomes, for its part, rarely examines new democracies - it focuses primarily on consolidated democracies such as the United States - and scarcely considers reversals in outcomes (Amenta et al. 2010). These two fields of study are partially bridged by the literature on nonviolent resistance, which studies the role of contentious collective action in democratic transitions through cross-national time series (Celestino and Gleditsch 2013; Stephan and Chenoweth 2008) and comparative case studies (Rueschemeyer, Stephens, and Stephens 1992; Tilly 2003). But this literature focuses almost exclusively on the emergence of democracy, not the survival of democracy. Building on insights from these literatures, as well as path-dependent analyses of democratic transition (e.g., Fishman 2011; Viterna and Fallon 2008), I ask how popular mobilization during transition affects the durability of new democracies. Whereas an earlier literature suggests that contentious mobilization undermines democratic stability (e.g., Huntington 1984), I argue that young democracies that originated in longer periods of unarmed mobilization are more durable. Sustained unarmed mobilization under authoritarian regimes requires an organizational infrastructure; this infrastructure can help shape the leadership in the new democratic regime and maintain links between society and the new state in the crucial post-transition period.

I use original data to test these two competing hypotheses about mass mobilization and democratic durability. An event history analysis of 112 young democratic regimes in 80 countries from 1960 to 2010 provides evidence that the duration of unarmed contentious mobilization is associated with the probability that an emerging democracy will survive. To illustrate the mechanisms that link unarmed campaigns to democratic durability, I analyze South Africa, which is a paradigmatic case for studies of society-led democratization. The significance 
of this case for a theory of contentious democratization is similar to the importance of France and Russia for theories of revolution.

\section{MASS MOBILIZATION AND DEMOCRATIC BREAKDOWN}

What shapes the fate of young democracies? The issue of democratic decay versus stability has long been a central issue in political sociology (Ermakoff 2008; Higley and Burton 1989; Lipset 1994; Marx [1852] 1994; Tocqueville [1835] 2002). In his long durée study of democracy and contention in Europe, Tilly (2003:13) notes that "although democracy has, indeed, become more prevalent in recent centuries, de-democratization still occurs frequently and widely." Why do some democracies break down after military coups or through the violation of democratic procedures by elected officials, while other democratic regimes survive such challenges?

Research on democratic breakdown has focused on elites' strategic choices and preferences (Linz and Stepan 1978; Mainwaring and Pérez-Liñán 2013), economic development (Boix 2011; Lipset 1994; Przeworski and Limongi 1997), natural resources (Ross 2012), institutional design (Kapstein and Converse 2008), international context (Wejnert 2005), and the institutional form of the antecedent regime (Linz and Stepan 1996; Svolik 2008). These studies expand our understanding of democratic durability, but they do not recognize that there might be different pathways to democracy, and these different routes might affect the probability of democratic consolidation.

As Tilly (1995) once commented, democracy is like a lake: water may fill the lake from different origins and routes. Democratic transitions may occur as a result of international intervention and brokerage among the elite (Haggard and Kaufman 2012). Popular uprisings are only one potential pathway toward democratization. One may thus ask, do democracies emerging from popular mobilization possess characteristics dissimilar to other democratic regimes? More specifically, are such democracies more or less durable?

Some years ago, an important body of work proposed that the mode of transition also affects the fate of democratic regimes - namely, that democratic transitions led through elite pacts resulted in more sustainable democracies (Higley and Burton 1989; Munck and Leff 1997). I refer to this literature as the elitist approach to democratization. Huntington (1984:212), a major figure in developing this line of thought, affirms this elitist bias against mass mobilization, writing that "democratic regimes that last have seldom, if ever, been instituted by mass popular actors." According to this view, stable democracies are built when softliners in a regime and moderates in the opposition agree on certain parameters of transition and the new democracy. At this stage, political elites' negotiation skills in reaching a compromise are significant. Mass mobilization, however, might destabilize the political order, pose a threat to the interests of authoritarian elites, such as the armed forces, and encourage them to reverse the newly initiated democratic process (Huntington 1993; O'Donnell and Schmitter 1986). Additionally, a contentious civil society might overload the political regime with various demands. When political institutions are weak, associations might undermine political stability and democracy by "deepening cleavages, furthering dissatisfaction, and providing rich soil for oppositional movements. A flourishing civil society under these circumstances signals governmental and institutional failure and bodes ill for political stability and democracy" (Berman 1997:427).

Because political institutions are often underdeveloped in new democracies, one might expect to see anti-democratic tendencies from protest movements in such regimes. The failure of the uprisings in the Arab Spring to create stable democracies could serve as an example for the elitist approach. The uprising that initially brought down the long-standing dictator Hosni Mubarak in 2011 later set the stage for a popular coup and crackdown on different factions that had organized the 2011 revolt (Kethcley 2017). The resulting disappointments led some 
scholars to state that mass uprisings often show anti-democratic tendencies, and to question whether social movements can detonate democracy (Howard and Walters 2015). Based on the elitist approach, one can hypothesize that democracies born out of episodes of mass mobilization do not last long.

\section{POPULAR MOBILIZATION AND DEMOCRATIC DURABILITY}

Comparative historical sociology, on the other hand, points to the positive role of popular upheavals in democratization. Moore (1966) argues that democracy is achieved through bourgeois revolutions. Rueschemeyer, Stephens, and Stephens (1992), in contrast, demonstrate that democratization has been achieved through working-class mobilization. Kurzman (2008) documents the role of intellectuals in democratic uprisings of the early twentieth century. Finally, McAdam, Tarrow, and Tilly (2001:269) conceptualize democratization as an important phenomenon in the broader family of contentious politics and contend that "[d]emocracy results from, mobilizes, and reshapes popular contention." Case studies of more recent democratizations (Bratton and Van de Walle 1997; Schock 2005), as well as cross-national analyses (Alemán and Yang 2011; Celestino and Gleditsch 2013), also document the positive effects of popular mobilization on democratic transitions. This scholarship recognizes the effect of mass mobilization on democratization, but it mostly focuses on short-term effects of protest on democratic transition, rather than the durability of new democracies.

Some studies highlight more long-term effects of mass upheavals. Skocpol (1979) argues that social revolutions significantly increase the mobilization capacities of emerging states. Similarly, Levitsky and Way (2013) demonstrate that post-revolutionary authoritarian regimes boast higher survival capacity than do other autocracies. Viterna and Fallon (2008) argue that women's mobilization during democratic transitions helps women's mobilization in posttransition politics. Building on these studies, this article demonstrates that democracies that have their origin in longer unarmed campaigns have a higher chance of survival than do other democratic regimes.

Despite pessimism about the repercussions of mass mobilization in the elitist approach, I argue that anti-dictatorship popular mobilization may increase the durability of emerging democratic regimes. Unarmed popular campaigns that mobilize over a long period of time generate an organizational structure that provides a leadership cadre for the new regime, forges links between the government and society, and strengthens checks on the power of the post-transition government. This focus on the organizational legacy of movements has important implications for studies of social movement outcomes. Some political sociologists argue that movements are rarely influential, as compared with state-structural and other factors (Giugni 2007; Skocpol 2003). Other scholars, however, believe that movement mobilization matters for policy change. Studies on the effectiveness of movements point to factors such as political mediation (Amenta, Caren, and Olasky 2005), strategy (McCammon et al. 2008), and organization (Andrews 2001). This article demonstrates the importance of social movements to democratic durability, and I argue that the organization-building side of mobilizations shapes outcomes.

The duration of mobilization matters for the durability of post-transition democracies, because popular campaigns typically require a solid organizational infrastructure to survive under repressive conditions (Andrews 2001). Short episodes of unrest may occur without much coordination; these uprisings may rely on personal networks (Opp and Gern 1993), because informal networks are less vulnerable to repression. However, for movements to expand into a sustained political challenge and to mobilize over an extended period of time, they need to generate or expand a structure of formal organization ${ }^{1}$ (McAdam 1999). Formal organizations are crucial in bringing various resources into movements, and they are also more likely to engage in activities that maintain and expand movements (Edwards and McCarthy 2004; 
Staggenborg 1988). Even though social movement organizations may take both formal and informal forms, the existence of formal organizations might be necessary for the survival of anti-authoritarian movements and their broader consequences after a transition. A high-capacity organizational buffer enables movements to recover in the face of government repression, change their tactics, and keep their supporters connected and motivated under severe conditions (Ganz 2010). ${ }^{2}$ Studies of social movements under authoritarianism suggest it helps formal oppositional organizations to have a degree of decentralization (Schock 2005) and to be embedded in informal networks (Loveman 1998). When repression targets movement organizations' summit, decentralization features and embeddedness in informal networks help movement branches and affiliates to regroup and recover. The duration of mobilization, in other words, may indicate the degree to which mobilization has been translated into organization.

Moreover, studies of nonviolent resistance demonstrate that sustained and successful nonviolent campaigns usually engage a larger number of participants than do violent ones. This is partially because of the nature of unarmed tactics such as strikes and boycotts. Armed operations may be carried out by a smaller group of activists, but a successful boycott, strike, or demonstration requires mobilization of a considerable portion of the population (Nepstad 2011; Stephan and Chenoweth 2008); movements must build vast organizational structures to train and coordinate such tactics among members.

The relationship between protest mobilization and organization is two-way. Formal organizations are necessary for sustaining mobilization, and protest itself revitalizes, reinforces, and reorients organizations in different ways. First, protest mobilization could provide information necessary for organization-building or about the reach of grievances. Participants in a spontaneous protest event could be motivated to form or join formal movement organizations. Massive protest could also create solidarity, popularize leaders and organizations, and encourage more recruits to join a movement. Collective action may also affect organizations' strategic and tactical choices. Militant mobilization, for instance, may push organizations to take a more confrontational stance in strategy and tactics and resist incentives for cooptation. Furthermore, protest mobilization can provide political opportunities for organization-building. Protest could result in repression, but protest movements can also create their own opportunities; in the wake of protest waves, for example, authorities might decide to provide limited political reforms to prevent further unrest (see Beissinger 2002; Edwards and McCarthy 2004; Kurzman 2004; Oliver 1989).

Other factors could also contribute to the longevity of a movement. Consistent with studies of political opportunities (e.g., Meyer 2004), authoritarian incumbents sometimes decrease the level of repression and open up the political scene for organizing. Organization-building in these periods helps sustain a movement in more repressive eras (Almeida 2003). Foreign supporters could provide resources and support for a movement, although some studies point to the contradictory effect of external support for nonviolent movements (Bob 2005). The strength of political regimes might also matter for the durability of democracy movements. A weak regime might quickly concede or collapse in the face of a popular uprising. A powerful and oppressive regime, however, would likely suppress any form of public resistance. Long movements might be more likely under regimes that neither easily collapse in the face of mobilization nor are able to completely kill a movement.

I propose that sustained popular campaigns contribute to the durability of emerging democratic regimes through their influence on the political leadership and civil society of the post-transition polity. First and foremost, such a campaign has a better chance of replacing authoritarian incumbents with democratic activists who have emerged as viable leaders during the years of struggle. Mass mobilization against an autocratic regime creates a momentum that may marginalize authoritarian leaders in post-transition politics. Short episodes of unrest may fail to 
launch new leaders into the new polity, whereas an important outcome of years of popular struggle is a set of leaders with credible democratic convictions and proven leadership experience to serve in the new regime. Prolonged movements are crucial to generating a leadership cadre in at least two ways. First, the day-to-day work and experience involved in building and maintaining complex movement organizations train cadre who can later translate these skills when the struggle shifts from protest to institutional politics in the transition and post-transition eras. This is perhaps the case for mid-level activists and leaders. Second, continuing defiant mobilization popularizes and endorses leaders at the summit of the movement and gives them a hegemonic position in the post-transition era. This mechanism applies more to leadership at the summit of movement organizations, and as studies of social movement leadership suggest, leaders of these organizations make the highest level of leadership in movements (Morris and Staggenborg 2004). Studies of post-communist politics indicate that stable democracies have resulted from cases where the opposition was powerful enough to replace the communists, whereas emerging democracies without powerful prior opposition faced serious incumbent turnovers, authoritarian setbacks, and even the resurgence of authoritarianism (McFaul 2002). The presence of a committed democratic leader, like Lech Walesa in Poland, could maintain public support for the difficult process of democratic consolidation (Ekiert, Kubik, and Vachudova 2007).

Sustained mobilization may also place democratic forces in a hegemonic position to negotiate the parameters of transition, build new democratic institutions, and rein in the privileges of authoritarian institutions such as the military. Nonviolent campaigns have been effective in inducing defection in the armed forces (Chenoweth and Stephan 2012). In the long run, prolonged unarmed movements could decrease the likelihood of coups, which are an important mechanism of democratic breakdown, by pushing back militaries from interfering in politics. In such situations, prolonged mobilization would signal to the military that a military's reinvolvement in politics would be costly. When such a hegemonic force is absent, and the transition is due to elite pacts, it is less likely the elite will ensure "horizontal accountability" (Diamond 2009).

This could be contrasted with recent rapid and massive waves of protest enabled by social media. Digital media has enabled activists to skip required organizing efforts and launch massive waves of contention without building any organizational infrastructure or prior coordinating. This new mode of mobilization, however, has had longer-term consequences for these movements. For instance, although these movements have initially been able to mobilize without defined leadership, in later phases the lack of leadership makes them unable to negotiate with the authorities, or even inside the movement itself, to define goals and set an agenda (Beissinger 2017; Tufekci 2017).

Long mobilization requires building alliances and agreeing upon leadership for the movement, but short waves of mobilization can succeed without building strong alliances between various groups opposing dictatorship. In such occasions, the only issue holding together the antiauthoritarian coalition is hatred of the incumbents (Beissinger 2013). When the incumbents are toppled, pro-democracy forces lose their only reason to stay together and may not agree on a transition agenda. Again, in such situations, if the active political forces fail to reach an agreement over the leadership and necessary steps for the post-dictatorship period, their disagreements could result in violent confrontations, alliance with old regime holdovers, an unstable democracy, or even democratic breakdown. Disputes about the parameters of the transition highlight another important mechanism of democratic breakdown.

In addition to providing emerging democracies with capable leaders, political parties may be formed out of the organizational structure and activists of the pro-democracy movements (Desai 2001; Lee 2016). Political parties are crucial actors in the process of democratic consolidation. 
Parties contribute to legitimation of the new regime as well as articulating and representing social demands (Diamond 1999; Linz and Stepan 1996). The organizational structure of a long pro-democracy campaign may also form part of civil society in the new democratic regime (Ekiert and Kubik 1999). Activists popularized and experienced in years of struggle often take leadership positions in civil society groups after transition (Chang 2015). Institutions of civil society enhance democracy in various ways: they may foster democratic values among citizens, teach political skills, promote the quality of representation, facilitate public deliberation, and provide opportunities for citizens' direct participation in governance (Fung 2003; Putnam 2001). With a well-functioning and connected civil society, different grievances and demands are channeled within the democratic system rather than against it. As Gramsci (1971) once argued, civil society organizations function as an extension of the state and enhance the political regime by promoting the state's hegemony and incorporating citizens into the existing political order. Electoral democracies, as regimes of power, function more effectively when they are inclusive and well-linked to society. Democratization campaigns also contribute to post-transition civil society's capacity to check and balance political power. The campaign may provide an organizational structure to organize new protest activities that hold politicians accountable or make new demands on the government. Also, years of political struggle against an authoritarian regime may enhance a group's protest tactics, as part of its claims-making repertoire, and provide inspiration for new social movements and campaigns in the post-transition polity (Chang 2015; Fishman 2011). An empowered civil society can then resist certain threats to democracy. For instance, when democratically elected incumbents try to change institutional checks, such as constitutional term limits, to undemocratically ensure their grip over executive power, citizens might mobilize and stop such attempts (Yarwood 2016).

Some social movement studies argue that formal organizations tend to opt for more conservative tactics and demobilize a movement (Piven and Cloward 1979). This argument, however, has been mostly developed in the context of democracies where institutional venues are available. In the context of repressive regimes, when no opportunities are left for articulating demands, it is less likely that formalization of opposition will lead to its demobilization. After the democratic transition, when the opposition takes the leadership position, we are more likely to observe tendencies pertaining to the iron law of oligarchy and demobilization processes. In short, although mass organizations may lead to some demobilization tendencies, without them, sustained mobilization in repressive contexts is more unlikely.

The path of prolonged mobilization and its features contrasts with other pathways, such as those resulting from elite brokerage, international intervention, or post-civil war settlements. These different paths have their issues in the process of democratization. For instance, as discussed earlier, transitions resulting from elite brokerage are less likely to feature popular leaders with democratic convictions, marginalization of authoritarian holdovers such as militaries, or strong institutional checks. Transitions resulting from international interventions may not enjoy the grassroots support necessary to keep democratic powerholders in check (on other pathways of democratization, see Haggard and Kaufman 2016). Finally, post-civil war democracies have serious challenges in transforming militants into civilian parties. They also usually accompany the active presence of international actors, who may shift the agenda of civil society organizations away from their grassroots base (on the challenges of post-civil war democracy and civil society, see Belloni 2008; Huang 2016; Kovacs 2008).

\section{THE UNIVERSE OF CASES}

The pool of cases in this study consists of electoral democracies that emerged after 1950. To generate the full set of such democracies, I used a new dataset of political regimes (Geddes, Wright, and Frantz 2014). A political regime is considered democratic when the executive achieves power through "direct, reasonably fair, competitive elections" (Geddes, Wright, and 
Frantz 2014:317). An election is not considered competitive if a major party is excluded from the competition, if there are widespread reports of violence or intimidation against the opposition, or if incumbents dominate resources. Studies of democratic survival often start with a dataset of democracies. There are different approaches to identifying democratic regimes. One approach uses continuous measures of democracy, such as Polity IV, and uses a cutoff point. I prefer a dichotomous measure, because continuous scores are derived from scores in subcomponents, and thus cutoffs are not based on any clear theoretical definition. Dichotomous measures similar to the one used in this study, however, clearly define what conditions are to be met for a country to cross the threshold.

Dichotomous measures do have their own shortcomings. Transitions to democracy are sometimes ambiguous, so there is unlikely to be full agreement across indices. I recognize this limitation, and I use a different dichotomous measure of democracy (Cheibub, Gandhi, and Vreeland 2010) to define an alternative universe of cases. Geddes Wright, and Frantz' (2014) dataset has a slightly higher bar-it requires minimum suffrage and party competition, which are not conditions specified in the alternative measure.

Admittedly, this is still a minimal definition of democracy. It does not, for example, entail that the military be subordinated to civilian rule, or that constitutional protections be in place for minorities. There are advantages and disadvantages to choosing a high or low bar for democracy. Choosing a high bar makes it more certain that all regimes in the sample are true democracies, but it could also conflate democratic breakdown with a downgrade in democratic quality that does not culminate in a full democratic failure. A low bar, on the other hand, would include weaker democracies in the sample that are more likely to collapse. If the strength or weakness of democracies is associated with their origins, then it would be in my theoretical interest here to opt for a low bar and include those democracies in the analysis, as they potentially add more variance in the dependent variable. ${ }^{3}$

Using this measure, there are new 115 electoral democracies from 1960 to 2010. Because of missing socioeconomic data, I drop three regimes from the analysis. ${ }^{4}$ Of the remaining 112 cases in the 80 countries I consider, 48 cases (42 percent) suffered democratic breakdowns between 1960 and 2010, and 65 regimes remained democratic in 2010 (see Table 1 for the list of these democracies). For each democratic regime, I calculated age from the first year of its existence until either democratic failure or the end of the analysis in 2010. The average age for failed democracies is 6.1 years, with a median age of four years. For democracies that survived until 2010 , the average age is 17.6 , with a median of 18 . This analysis only includes countries when they are democratic. Countries are not included in the sample before democratic transition or after democratic breakdown. Note that a given country sometimes has multiple regimes; some countries experienced multiple democratic transitions and breakdowns.

\section{<Table 1 about here $>$}

\section{MEASURES}

Democratic failure. The dependent variable of this study is time to democratic failure. Democratic regimes fail when executive power is achieved through means other than reasonably competitive elections, including coups, foreign occupation, civil war, and rebellion. A democratic regime is also considered to have failed if freely elected incumbents subsequently limit political competition through changes in formal or informal rules. Such changes include banning opposition parties, forcing opposition parties to merge with the dominant party, closing the legislature unconstitutionally, harassing the opposition, engaging in vote fraud, and annulling election results. 
Mobilization at democratic transitions. I created an original dataset for the primary independent variable of this study: the duration of popular campaigns contributing to a democratic transition. Following Chenoweth and Stephan (2012) and Tilly and Tarrow (2015), I define a popular campaign as comprising at least 1,000 people participating in a series of contentious collective actions to make demands on a government. I only focus on campaigns that primarily rely on unarmed methods of contention, because studies of nonviolent and violent mobilization demonstrate that these campaigns have considerably different dynamics and consequences. Nonetheless, I use a measure of armed campaigns as a control in the robustness tests. I used a wide array of secondary sources to identify whether popular mobilization was influential in the course of any given transition, and over how many calendar years the mobilization occurred. In order of importance in data collection, I relied on analyses of transitions by social scientists, historians, and, for more recent cases, reports from organizations such as Freedom House on major political developments in a country. Based on these sources, I identified major episodes of mobilization that contributed to democratic transition, and I accordingly constructed the length of mobilization. These sources usually identify the first contentious event in the campaign. For several cases, one source was sufficient to establish the duration. If such an analysis did not exist or did not provide enough information about the importance or exact instances of mobilization, I consulted other sources. ${ }^{5}$ I chose these sources based on their importance as social scientific analyses of the transition. For each case, I present a short narrative that describes the transition and the incidents of contention contributing to the transition. ${ }^{6}$

An important concern about the quality of data collected on popular campaigns based on secondary sources arises from the fact that there may well be nonviolent, failed campaigns these sources do not cover. Armed and successful unarmed campaigns catch more attention than do unarmed ones. Claims about the effectiveness of unarmed campaigns may thus sometimes rest on defective data in which nonviolent failure is underrepresented (Lehoucq 2016). This concern is important, but it is less relevant to my data than to other measures of nonviolent campaigns. This is because all the potential campaigns in my universe of cases were initially successful in bringing about a democratic transition. This initial success makes the campaign more newsworthy, even though the new democratic regime might have collapsed later.

I also checked my coding against two existing datasets. The first dataset, by Chenoweth and Cunningham (Chenoweth and Stephan 2012; see also Chenoweth and Cunningham 2013), gathers an impressive list of violent and nonviolent campaigns for the whole twentieth century. The second dataset, by Haggard and Kaufman (2012), focuses on the role of mass mobilization prompted by economic grievances in democratic transitions from 1980 to 2000, covering a subset of my cases. My coding usually matches that of Haggard and Kaufman (2012), but it differs from Chenoweth and Stephan (2012) in many instances. Some popular transitions leading to failed democracies, such as Sudan in 1966 and Peru in 1981, are included in my dataset but not identified in theirs. The different coding of these cases has reduced the bias against failed nonviolent campaigns in the existing datasets. In a few cases of successful democracy, such as Ghana in 2001, Chenoweth and Stephan (2012) identify a campaign as important for democratization, although the secondary literature describes an elite-driven transition with little or no reference to protest. I coded such cases as lacking popular prodemocracy campaigns. There were also cases that both datasets identified as a popular campaign, but my dataset provides more careful documentation of the specific instances of protest mobilization and subsequently the length of the campaign. This is perhaps because the other two datasets collected data on all protests, but I was specifically interested in protests leading to democratization, which allowed me to conduct more targeted research. Despite these differences, my findings hold up in models using Chenoweth and Stephan's coding of popular campaigns. Finally, in this data I only explore the duration of the mobilization, but other aspects of a mobilization, such as its breadth or intensity, could be important for its long-run 
consequences. Future data on those dimensions could improve our understanding of different dimensions of contentious mobilization.

As a proxy for the strength of democratic movements, I use the number of years that the popular campaign lasted. There is theoretical reason to believe that the duration of contention is a good proxy for a movement's organizational strength. Movements without solid organizational infrastructure are less likely to be sustained over the long term in the repressive context of authoritarian regimes. This measure is preferable to other feasible alternatives. It is possible that this measurement strategy will not capture times when a movement is in abeyance. This would be an error, but it would be biased against my argument. Abeyance is not newsworthy for journalists and has received less attention from social movement scholars. As a result, we tend to know more about abeyance periods for successful longer movements. Coding for abeyance would result in longer movements being coded even longer, favoring my argument. Coding public protest rather than organizing in abeyance would generate a less biased measurement in support of my argument. Furthermore, organizing underground does not have some of the effects of public protest, such as popularizing and certifying movement leadership. The cutoff point of 1,000 participants should also help address potential reporting bias (i.e., that smaller protests are reported less reliably across cases). According to these criteria, 65 (58 percent) of the 112 transitions in this study were preceded by unarmed popular campaigns. Figure 1 shows the frequency of unarmed campaigns' duration during these transitions.

\section{$<$ Figure 1 about here $>$}

Controls. This analysis also includes a series of variables to control for rival explanations. First, I introduce controls to account for several economic confounders. It is possible that the association between the length of unarmed campaigns and democratic survival is driven by the level of economic development, given that economic prosperity promotes democratic consolidation (Boix 2011; Przeworski and Limongi 1997), strengthens civil society, and provides more resources for opposition groups to campaign against the government (Rueschemeyer et al. 1992). Thus, I include GDP per capita in U.S. 2005 dollars (World Bank 2012). Scholars also argue that oil revenues might enable democratically elected incumbents to consolidate their power through undemocratic means and thus undermine democracy (Ross 2012), and that oil-producing countries tend to have lower rates of protest activities (Smith 2004). Hence, one could argue that the association between popular campaigns and democratic failure is determined by oil production. To control for this rival explanation, I include a variable for oil production per capita in U.S. 2000 dollars (Ross 2012). Because economic performance is an important predictor of both democratic survival (Bernhard, Nordstrom, and Reenock 2001) and rates of protest (Caren, Gaby, and Herrold 2017), I include a control for GDP growth in annual percent (World Bank 2012).

\section{$<$ Table 2 about here $>$}

I also introduce controls to test political explanations of the association between democratic movements and democratic survival. A country's democratic history might have an effect on both the chance for democratic durability and the strength of movements. Previous democratic experiences could set the foundation for democratic institutions and also provide a base for activism. To control for this potential effect, I include a variable accounting for the years a country has been democratic before the current democratic spell. Studies of democratic consolidation contend that the antecedent regime has an important effect on the survival of democracies (Linz and Stepan 1996), with democracies that follow military regimes having lower chances of survival (Svolik 2008). Accordingly, one might argue that an association between democratic movements and democratic survival is a byproduct of previous 
authoritarian regimes. I include dummy variables from Geddes Wright, and Frantz (2014) to indicate if previous regimes exhibited military, personalist, or party elements. I also include a variable for post-independence democracies. To address the extensive scholarly debate on the effects of presidential versus parliamentary systems on democratic durability, I include dummy variables for mixed systems and presidential systems versus the excluded category of parliamentary systems. ${ }^{7}$ I use Beck and colleagues (2001) as my main source of coding and use Cheibub and colleagues (2010) and Banks and Wilson (2013) for country-years not covered in the first dataset.

Research also shows a strong regional effect on democracy promotion, as democracies usually emerge in waves (Wejnert 2005). Similarly, protests sometimes diffuse regionally (Kadivar and Caren 2016). Thus, an alternative explanation for the association of popular campaigns and democratic survival could be a regional effect. To account for this hypothesis, I include a variable that captures the proportion of democracies in each geographic region in each year.

Ethnic fractionalization in a country and exclusion of ethnic groups might also undermine a young democracy and render armed conflict a more likely method of contention. Accordingly, I include two variables from the Ethnic Power Relations Data Set, Version 3 (Wimmer, Cederman, and Min 2009) to control for ethnic fractionalization and the size of the population excluded from the policy process in each country (see table 2 for summary statistics).

\section{QUANTITATIVE METHOD}

To evaluate the impact of contentious transitions on the chance of democratic survival, I use Cox proportional hazards models, a well-established method for modeling event history (also known as survival analysis) (Cox 1972; Cox and Oakes 1984). As noted earlier, the unit of time is years, beginning with a country's democratic transition and ending with democratic failure or censoring at the end of the study period in 2010. Ties (i.e., countries that experienced democratic failure after the same number of years) were handled using the Breslow method. Democratic survival rates are modeled as a function of my key independent variable and potential confounding covariates. Robust standard errors are reported to adjust for the clustering of multiple democratic regimes in a single country. ${ }^{8}$ The Cox proportional hazards model constrains the ratio of hazards at different levels of the independent variables to be constant over time. The Schoenfeld residuals test indicates the proportional hazards assumption is reasonable for my model (global test chi-square $=11.91,15 \mathrm{df}, p$-value $=.68$ ).

In auxiliary analyses, I explored the possibility of using fixed-effects models to address potential bias from country-invariant omitted variables. The within-country analysis, however, resulted in the loss of 66 percent of the sample due to a lack of variation in unarmed duration, and thus was not feasible. My analytic strategy relies on the assumption that there are no omitted confounders to warrant a causal interpretation of the estimate of unarmed mobilization length on democratic survival. This is a strong assumption, but the set of controls outlined above addresses the primary confounders, and the case study provides further evidence to support the relationships uncovered in the event history analysis.

\section{EVENT HISTORY ANALYSIS}

Among the 65 democracies that originated in unarmed contention, 39 regimes survived until the end of the analysis and 26 failed. Among the 47 regimes whose transition was not marked by unarmed mobilization, 25 survived and 22 collapsed. $^{9}$

The average duration of unarmed mobilization was 1.6 years. The average unarmed mobilization for newly democratic regimes that survived was 1.9 years, as opposed to only 1.2 
years for democracies that eventually broke down. The duration of popular mobilization was longer in democratic regimes that survived and statistically significant in a two-sample $t$-test ( $p$ $=.03$ ) — contrary to the elitist approach.

Table 3 presents the results of event history models of democratic survival. The covariate for unarmed mobilization duration is negative and remains statistically significant net of all control variables (Models 1 and 2). This result suggests that the elitist approach is wrong: the length of unarmed mobilization is positively associated with the probability of democratic survival. ${ }^{10}$

$<$ Table 3 about here $>$

Models 3 and 4 test whether it is the mere occurrence of unarmed mobilization that matters for stability or whether duration matters. I do this in two ways. First, Model 3 only includes democracies in the pathway of mobilization. I exclude from the sample all democracies that emerged without mass mobilization to see whether length of mobilization could explain variation in the mobilization pathway. Even though this model restricts the sample considerably, the covariate for the length of mobilization stays significant. Second, Model 4 includes a dummy variable denoting whether the transition was preceded by unarmed mobilization of any length. The coefficient is negative but not statistically significant, which is in keeping with the main hypothesis of this article. The length of unarmed mobilization is associated with a decrease in the chance of democratic breakdown, but the mere occurrence of a mobilization does not predict democratic survival. To observe the effects of mobilization, we must take into account its duration.

Keeping other variables at their observed values, the relative hazard of breakdown for a democracy with one year of unarmed mobilization is 18 percent smaller than a democracy that emerged without unarmed mobilization. A democracy that originated in three years of unarmed mobilization has a relative hazard of failure 33 percent smaller than a democracy with one year of unarmed mobilization. And a democracy emerging from six years of mobilization has a relative hazard of failure 44 percent smaller than a democracy with three years of mobilization, 62 percent smaller than a democracy with one year of mobilization, and 69 percent smaller than a democracy in which unarmed mobilization did not occur. (I computed these relative hazards from Table 3, Model 2.) Figure 2 shows the cumulative hazard of democratic failure for young democratic regimes emerging from different durations of unarmed mobilization. The figure shows that young democratic regimes in the analysis consolidate in about two decades, but within these two decades they experience different levels of risk of failure. Young democracies originating in longer unarmed campaigns run smaller risks of failure than do democracies with shorter campaign durations or those without any history of unarmed mobilization.

\section{$<$ Figure 2 about here $>$}

The controls in the models let us rule out a number of potential endogeneity threats. Based on these variables, we can conclude that the association between the duration of unarmed mobilization and democratic survival is not driven merely by the level of economic development, the antecedent authoritarian regime, previous democratic experiences, regional democracy, or ethnic configuration. The controls also suggest that higher levels of economic development, more democracies in a region, and previous democratic experiences are associated with a higher chance of democratic survival, whereas post-military democracies and mixed systems are more prone to democratic failure.

\section{Robustness Tests}

The correlation between the duration of unarmed mobilization and democratic durability is robust to different model specifications. One might wonder if extreme values of mobilization 
duration drive the size and statistical significance of the main independent variable. The main finding, however, is supported by additional models in which these longer mobilizations are excluded or when the log version of mobilization duration is used. The finding remains robust when the pool of cases is expanded to include all democracies that emerged after 1945, as well as when the pool is limited to democracies that emerged either after 1960 or before 2001. The result might also be sensitive to inclusion of countries with multiple democratic spells.

Countries with previous democratic breakdown might experience shaky democracies or, due to learning processes, have a better chance of survival. To address this concern, I excluded all democratic regimes with previous democratic experiences. The main finding is robust to this change in the sample.

For a different test of the spatial effect, I used a variable capturing the proportion of democratic regimes adjacent to a country, instead of using the proportion of democracies in a region. One might also wonder about a potential period effect. Due to changing transitional circumstances, more recent democratizations might be more durable. In particular, the post-Cold War era may be more favorable for democratic rule; moreover, anti-regime mobilizations have become more likely to be unarmed, and unarmed mobilizations have become more effective. To address this concern, I included a dummy variable for Cold War-era. To test for a regional effect, I included dummy variables for each region. My main finding is robust to these different specifications of spatial and period effects.

The finding is also robust to including more control variables, such as duration of violent mobilization leading to democratic transition, previous colonizers, years under colonial rule, armed conflict, share of government revenues in GDP, foreign aid, ties with international organizations, number of military personnel, and military expenditure in the pre-democratic regime. Separately, I included controls for different features of the political context, such as the state of civil society and civil liberties, including formation of associations before the start of the campaign and the transition. These measures address an endogeneity issue similar to the political opportunity thesis in social movement studies (e.g., Meyer 2004), according to which more open or less repressive authoritarian regimes lead to longer social movements and more durable democracies.

I also included controls for a country's trade with the United States and the European Union, as the main democratic superpowers, and with Russia and China, as the main authoritarian superpowers. These controls test whether economic linkages with democratic and autocratic superpowers drive the association between mobilization and democratic survival. The main finding is robust to all these changes in model specification. Because some studies of democratic survival use event history models with the assumption of a Weibull distribution of hazard ratio, I confirmed the robustness of my model using this assumption.

I also used Chenoweth and Stephan's (2012) dataset to construct an alternative measure for the duration of campaigns, with no change to the article's main finding. I built another alternative measure of campaigns based on my case summaries. In this measure, in addition to years of public mobilization, I also counted years of organizing, when no overt mobilization was reported, which again did not affect the main finding. To make sure the finding is not dependent on the identification of democratic regimes by Geddes and colleagues (2014), I coded democratic transitions according to an alternative dataset of political regimes (Cheibub et al. 2010) and reran the models. Finally, I ran all the models with both the alternative measure of democracy and the alternative measure of campaigns. The main finding is robust to these different specifications. ${ }^{11}$

\section{CASE STUDY: CONTENTIOUS MOBILIZATION AND DEMOCRATIZATION IN SOUTH AFRICA}


Contrary to the elitist approach, the event history analysis demonstrates a robust positive association between the length of unarmed campaigns predating democratization and the chance of survival for young democracies - but how can we explain this association? Statistical analysis is a powerful method for discovering empirical regularities in the occurrence of social phenomena, but qualitative methods are more effective in identifying the causal mechanisms underlying such regularities (Goertz and Mahoney 2012; Ragin 1989).

Accordingly, I examine mechanisms by which unarmed campaigns may affect the survival of young democracies through a case study of South Africa (1994 to the present). South Africa is a paradigmatic case: social movements led the country to a durable democracy, which furnishes an ideal opportunity to observe the mechanisms linking contention and durability. ${ }^{12}$ The country witnessed one of the longest mobilization campaigns for democracy in the twentieth century. In that sense, this case shows an extreme value on the independent variable. Extreme cases are valuable precisely because they show a phenomenon at its extreme, and thus are useful for investigating and theorizing that phenomenon. For instance, German Fascism has been used to theorize the phenomenon of fascism; the Holocaust is used to understand genocide; and the French and Russian revolutions are used to conceptualize revolutionary processes (Gerring 2006). Similarly, I propose to study South Africa to better understand the mechanisms involved in society-led democratization (Wood 2000).

I use secondary sources to present a narrative about how mobilization length contributed to the survival of democracy. Narrative analysis uses a strong method of inference to address temporally sequenced events and path-dependence, yet it may create idiosyncratic accounts (Mahoney 1999). To compensate for this potential shortcoming, I present the narrative in five major components: pro-democracy mobilization and its organizational infrastructure, democratic transition, the effect of the mobilization on leadership change, the effect of mobilization on civil society, and the role of these factors in the survival or failure of the new democracy.

\section{Campaign}

The anti-apartheid movement in South Africa is one of the longest struggles for democratic rights in the world. In 1950, the African National Congress (ANC) launched the Defiance Campaign, which organized stay-aways and mass strikes to protest racist policies enacted by the apartheid regime. Faced with severe repression, in the early 1960s the ANC moved to exile and changed its strategy to an armed struggle to bring down apartheid via a violent seizure of power. With this strategy, however, the ANC turned away from its mass base inside the country. The ANC was unable to pose a serious threat to apartheid, but it periodically launched armed attacks to remind both whites and Africans of its existence (McKinley 1997; Schock 2005; Wood 2001).

By the mid-1960s, the internal resistance had been cruelly suppressed within the country, and the ANC was isolated in exile. At this time, the Black Consciousness Movement (BCM) emerged and emphasized liberation from a sense of inferiority to forge black identity. The BCM avoided alliance- and organization-building in favor of direct confrontation with apartheid. The movement preferred methods such as plays, discussion, and example rather than protest tactics such as demonstrations or strikes (Marx 1992; Seekings 2000).

The BCM had gained some popularity among activists in the 1970s, but the Soweto uprising in 1976 to 1977 marked a turning point in the history of internal opposition. Although the revolt quickly spread to other towns, the South African government was able to completely crush the unrest. The uprising, however, showed the potency of contentious collective action and the 
importance of organizing. The BCM was credited for inspiring the uprising, but its organizational weakness was highlighted in the failure of the protest wave. There was no local organization to keep up discipline and momentum once repression began. The BCM also lacked any connection to labor, which was itself not well organized at the time (Marx 1992). As a result, some of the BCM's adherents were drawn to the ANC's approach, which emphasized organizing, alliance-building, and inclusiveness. Younger generations of BCM-inspired activists joined ANC camps in exile, and they pushed the ANC to merge armed struggle with mass struggle and to build an organizational infrastructure within the country (McKinley 1997).

The consequences of the Soweto uprising were not limited to the opposition. The apartheid government introduced a number of reforms seeking political and economic cooptation of nonwhites and easing pressure points. These reforms were aimed at splitting the movement based on racial differences, for example, by giving Indians and Coloureds more institutional access. Nonetheless, these reforms provided some open space for political activities of internal opposition (McKinley 1997).

In this context, new forms of protest and activism emerged in South Africa. Activists sought to organize South Africans around local grievances and later pressed for political reform. In 1983, these civic associations coalesced in the United Democratic Front (UDF) as an umbrella organization to coordinate its affiliates' activities. The group had a national body, composed of regional UDF bodies that coordinated highly diverse affiliates at the local level. The UDF's plan was to expand either through forging or enlarging organizations in new constituencies or through alliances with existing organizations. The Front connected disparate parts of the opposition, and it encouraged local activists to see themselves as part of a national movement. Specifically, the Front was successful in forging connections with black labor unions. The UDF emphasized highly organized methods of nonviolent resistance. It was also successful in raising funds from within and outside the country; by 1987, it had expanded its paid workers to 80 fulltime professionals. In their events, the UDF actively promoted and idolized the profile of the ANC and particularly Nelson Mandela. Among its first campaigns, the UDF organized actions to call for Mandela's release. The ANC found a valuable ally in the UDF, as they had a consistent approach in terms of non-racialism, alliance-building, and organizing. The ANC was also eager to counter the perception that it was an organization in foreign soil that drew its support from external sources (Marx 1992; McKinley 1997; Seekings 2000).

In 1983, the UDF opposed the new tricameral parliament, which was part of the regime's reform to coopt non-whites. In 1984, on the first day of the tricameral parliament, a revolt broke out in the Vaal township, protesting increasing rents. The revolt soon spread to other parts of the country and became the most intense mass struggle in the history of South Africa. The initial intensity and pace of the struggle took the UDF, ANC, and the South African Communist Party (SACP) by surprise. UDF activists soon took leadership of the upheaval. The ANC called on South Africans to make the country ungovernable and announced that their strategy had changed from guerrilla warfare to a people's war. Even though the UDF initially avoided confrontational tactics, the intensity of the revolt and the government's forceful repression changed their attitude. In this phase, the UDF decided to provide more effective leadership and changed its strategy from broadening the alliance to intensifying the revolt. In 1986, the government escalated repression by announcing a state of emergency. The UDF adapted its tactics to consumer boycotts and organizing street committees. In 1987, a second and more severe state of emergency was put in place, and in 1988 the UDF was officially banned.

The labor movement, the other powerful wing of the liberation struggle, led the movement through the next stage. Labor unions were allies of the ANC in the 1950s, but the government crushed those unions along with other internal opposition groups. A series of wildcat strikes in 1973 in Durban revived the labor movement in the country. Growing labor militancy, along 
with the Soweto uprising, prompted the government to introduce a series of labor reforms, including legalization of unions. Through mergers and organizing, emerging unions founded the Federation of South African Trade Unions (FOSATU) in 1979 with about 20,000 members. Unions used outsider (strikes) and insider (negotiations with employers) tactics, different from the revolutionary approach of ANC supporters. Accordingly, labor unions initially kept their distance from the internal political opposition. However, as the resurrection intensified, labor reevaluated its approach and started participating in political protests. In 1985, the Congress of South African Trade Unions (COSATU) was formed. FOSATU focused on shop floor issues, whereas COSATU maintained that unions must engage in community struggles and the broader political arena. Once the liberation movement was hit by the state of emergency in 1988, labor continued its activities using both negotiations and massive strikes. In 1989, the Mass Democratic Movement, founded by former members of UDF, prominent clergy, and COSATU affiliates, resurrected popular protest. COSATU was a strong partner in this alliance (Adler and Webster 1995, 2000; van Kessel 2000; Marx 1992; Seidman 1994).

Mobilizations such as those in Soweto and Vaal highlighted the importance of organizing, reoriented existing organizations to a more militant and inclusive stance, and brought together different wings of the movement. Mobilization also created opportunities for further organizing, when the apartheid regime introduced a number of liberalizing reforms to prevent further unrest. Additionally, organizations such as UDF and COSATU helped the movement reorganize during a time of repression, channeled resources to the movement, and popularized the leadership position of the ANC.

\section{Transition}

By 1989, the government and the movement were at an impasse. The government had not been able to completely suppress the movement, despite resorting to both stick and carrot tactics. Yet, even though the movement had created an economic and political crisis for the regime, the regime's coercive capacity was still intact. Consistently disruptive protests, however, had imposed considerable cost on the economic elite, which in turn pressured the white political elite to negotiate. In this context, the government and the liberation movement started negotiations. Mobilization in the 1980s and endorsements by main organizations such as UDF and COSATU had made the ANC the dominant opposition organization. The ANC and its ally the SACP were legalized again in 1990. The UDF dissolved and the ANC absorbed its leaders and supporters. Rounds of negotiations occurred from 1990 to 1994. In the face of negotiation impasses, the ANC threatened to withdraw from negotiations and return to protest. COSATU initiated mobilizations and general strikes to back the ANC's position. For instance, the National Party initially requested consociational power-sharing and veto power in the first cabinet. The ANC, however, rejected these requests and only agreed to include National Party members in the cabinet for five years, without veto power. The new South African constitution included universal suffrage, a Bill of Rights, an independent judiciary, and a new Constitutional Court. In 1994, South Africa held its first democratic election. Former UDF and COSATU members campaigned for the ANC; they had experience campaigning on the ground, which the ANC lacked at the time due to its years of exile. Many former UDF and COSATU members also stayed on ANC's national and provincial lists. The ANC won 62.5 percent of the vote (Adler and Webster 1995; Wood 2001).

\section{Leadership Change}

By 1994, the ANC was a vast popular political organization with a broad social base. The ANC formed an alliance with the SACP and COSATU and became the dominant political actor in South African democratic politics. Accordingly, the ANC's leaders took over leadership of the new democratic regime, with many mid-ranking activists in the anti-apartheid movement 
entering public office in the post-apartheid government. Mandela, the ANC's charismatic leader, served as South Africa's first president. The ANC's strict discipline, popularity, and diverse constituencies allowed it to manage the transition with no effective opposition and with the political stability needed for institution-building. After 1994, the ANC gained the majority of votes in all national elections, and it used this popularity to expand the institutional framework achieved in the negotiations through new legislations across a range of sectors such as local government, administration, public housing, and social services. The ANC also managed to avoid ethnic and sectarian contestations that have obstructed democratization in neighboring countries such as Zimbabwe (Butler 2005; Heller 2009). ${ }^{13}$

\section{Civil Society}

Years of organization-building during the anti-apartheid movement also contributed to the density of civil society organizations in South Africa. Two of the most important civic organizations founded during the democratic struggle, COSATU and the South African National Civic Organization (SANCO), continued to operate in the post-apartheid polity. As the biggest trade union in the country, COSATU played an important role in organizing workers in the antiapartheid movement. After 1994, it became a member of the tripartite ruling alliance and was successful in securing many pro-labor legislative initiatives and establishing corporatist institutions such as the National Development and Labour Council (NEDLAC), which were intended to ensure labor unions' influence (Buhlungu 2010). Similarly, legislation in 1995 recognized the right to strike and to organize at the plant level, and it created the Commission for Conciliation Mediation and Arbitration. COSATU also tried to affect policy through contesting right-leaning factions in the ANC. In that regard, COSATU's activities were influential in the leadership change from Thabo Mbeki to Jacob Zuma, even though the latter's policies have not proven significantly more favorable for labor conditions. In addition to insider tactics, COSATU has used militant mobilization in the workplace and on the street to push for labor rights. In August 2001, for instance, while the government was hosting the World Congress Against Racism, COSATU called for an anti-privatization general strike (Webster and Buhlungu 2004). ${ }^{14}$

SANCO, formed in 1992, had massive membership and many branches in the country. After 1994, many SANCO activists took government jobs, and SANCO's leadership was coopted by the ANC. As the ANC adopted new liberal policies, it needed to ensure the quiescence of civil society, so it tried to coopt and demobilize different sections, including SANCO. Accordingly, rather than a civic structure that facilitates the bottom-up process of shaping policy, SANCO has operated as the ANC's vehicle to deliver policies to local sites (Grodsky 2012; Heller 2009; Sinwell 2011; Zuern 2004). In this sense, SANCO still contributes to the density of civil society, but to the Gramscian image of a civil society that operates as the state's armor. ${ }^{15}$

Even though major organizations of the anti-apartheid movement, such as the ANC, have moved into government since 1994 and even pushed for demobilization, the rate of protest activities in South Africa has not declined but increased (Klandermans 2015; Runciman 2016). The methods of claims-making used in the anti-apartheid movement inspired several new social movements addressing issues such as housing crises, the HIV pandemic, service delivery, and land rights (van Kessel 2009; Robins and Colvin 2015). Some of these movements have made policy gains, the most important example being the Treatment Action Campaign's success in winning a comprehensive AIDS policy. These groups combined insider tactics of engaging with the government with outsider tactics of mobilizing grassroots support (Friedman 2012).

\section{Political Outcome}


The electoral democracy established in 1994 has survived for more than two decades. Long years of mobilization against apartheid demanded the involvement of strong political, labor, and civic organizations that contributed to the longevity of electoral democracy after apartheid was dismantled. The ANC, popularized during the pro-democracy movement, took political leadership after the transition and built new political institutions for a democratic South Africa, where it has remained the dominant political actor. Although the ANC has faced significant internal turmoil, its commitment to free and fair elections has never been under question. Moreover, it has abided by key court rulings against its government, which demonstrates its commitment to the separation of powers and the rule of law. Labor and civic organizations have also been able to link the democratic government and South African society. Efforts to coopt and demobilize civil society have not been completely successful. The anti-apartheid movement continues to inspire new social movements in South Africa, which have in turn provided new channels for bottom-up claims-making in the democratic process. Parts of civil society have been specifically mobilizing against ANC's dominance and its support for neoliberal policies. ${ }^{16}$

\section{CONCLUSIONS}

How does mass mobilization affect the fate of young democracies? The elitist approach contends that democracies emerging from mass mobilization rarely survive. Building on studies of nonviolent resistance, however, I argue that the duration of unarmed mobilization during democratic transitions predicts the success of democratic consolidation. I collected original data on mass mobilization during democratic transitions for 112 young democracies from 1960 to 2010. In contrast to the pessimistic view about the consequences of mass mobilization for democratic durability, an event history analysis of these democratic regimes shows a robust association between the duration of unarmed mobilization and the probability of democratic survival.

How does unarmed mobilization matter? I contend that sustained unarmed mobilization generates an organizational structure capable of providing a group of leaders with democratic convictions and leadership experience for the new democratic regime. It also creates statesociety linkages and reinforces checks and balances on the government. To illustrate these mechanisms, I presented a case study of South Africa as a paradigmatic case of democratization from below.

The case of South Africa shows how prolonged protest and organization-building went hand-inhand in the struggle period. Organizations such as COSATU and the UDF emerged inside the country and led the protest against apartheid. This wave of mobilization popularized the ANC's leaders in exile, as both organizations endorsed the ANC. ANC leaders, as the representatives of the movement, led the apartheid negotiations and took leadership of the new regime. The ANC, in partnership with SACP and COSATU, has participated and won fair and free elections since 1994. Movement organizations such as COSATU have also contributed to the strength of civil society.

Going forward, some puzzles remain. I have shown that the duration of mobilization in authoritarian regimes has important consequences for subsequent democracies, but what explains the longevity of some pro-democracy movements? The literature suggests that many factors might contribute: the introduction of political opportunities within the regime, the formation of a militant working class due to economic development, the organizational capacity of the opposition, the relative strength of the regime versus the movement, support from external powers, or cultural changes reinforcing oppositional identities, as highlighted by studies of social movements and nonviolent resistance. This article focuses on the consequences of sustained mobilization rather than its causes. Future research might tell us more about what contributes to the resilience of social movements in authoritarian settings. 
Furthermore, this article highlights the importance of formal organizations in sustaining mobilization under authoritarian regimes and also translating mobilization effects into longerterm democratic stability. Previous research tells us that embeddedness in informal networks helps formal movement organizations survive under repression (Loveman 1998). Future scholarship might take further steps in exploring how different organizational forms and templates of social movements would contribute meaningful democratic change in the long term.

The explanation for democratic durability presented here contributes to a broader framework that highlights the social foundation of political regimes and their hegemonic position as the main context for their durability. Explaining the resilience of capitalist states in Western Europe, Gramsci (1971) pointed to the social foundation of their political regimes in education and religious organizations among other domains in civil society. Building on Gramsci's theory, Riley (2010) highlights the associational foundation of Fascism in Italy as the main source of the regime's strength. Similarly, Levitsky and Way (2013) argue that post-revolutionary authoritarian regimes appear more resilient than do other forms of authoritarian governments. Emerging from episodes of mass mobilization, these regimes benefit from the presence of powerful ruling parties with a high mobilizing capacity based on extensive networks of supporters that penetrate the entire national territory. These ruling parties also have a leadership cadre with extraordinary legitimacy and unquestioned authority resulting from years of revolutionary struggle. These mechanisms are indeed similar to the mechanisms discussed in my argument that democratic regimes emerge from sustained pro-democracy movements. Nonetheless, there are mechanisms connecting popular mobilization and the longevity of authoritarian regimes that are different from my discussion of democratic regimes. Postrevolutionary authoritarian regimes destroy all independent sources of power and rival organizational structures in society, and they build enhanced coercive apparatuses. This is not the pattern I observed in the cases I studied. Nonetheless, future research might consider the differences and commonalities between post-mobilization democratic and authoritarian regimes.

This article also contributes to the literature on the formation of civic groups by suggesting that post-transition civil society organizations might have their origins in an earlier episode of oppositional mobilization. The strength of pre-mobilization civil society might contribute to oppositional mobilization, but the case studies show that movement activities make a significant contribution to the formation of civil society. In countries such as South Africa and Poland, for instance, grassroots mobilization against the antecedent authoritarian regimes led to the formation of important trade unions - COSATU in South Africa and Solidarity in Poland. Along with creating organizations for civil society, oppositional mobilization contributes to the post-transition civil society by bringing together otherwise fragmented groups and forging solidarity between them. For a civil society to serve democracy, it is important that civic groups demonstrate cooperative rather than conflictive behavior, especially in the initial phase of institution-building after a democratic transition. Escalation of conflict on those stages may lead to the collapse of democratic order.

My findings on the association between sustained mobilization and democratic consolidation serve as an example of how the literature on social movements and political sociology could be profitably combined. The results illustrate that contentious action is part and parcel of the practice of politics. Recent scholarship on democratic survival does not recognize the implication of different pathways to democracy for democratic durability (Kapstein and Converse 2008). On the one hand, an earlier literature on democratic transitions identified the importance of different transition modes for democratic stability, but believed that popular contention was unfavorable for democratic durability (Karl 1990). The scholarship on nonviolent resistance documents the positive effect of contention on democratic transitions, but 
it does not pay attention to the durability of new democracies (Chenoweth and Stephan 2012). On the other hand, studies that examine the longer-term effects of mass mobilization during political transitions investigate outcomes other than democratic consolidation (Viterna and Fallon 2008). This article brings all these literatures into dialogue with each other, makes the case that the mode of transition affects democratic durability, disputes pessimistic views about the effects of mass mobilization, and extends the scholarship on the impact of unarmed contention to the outcome of democratic durability.

This article also contributes to the study of social movement outcomes, which has focused largely on policy change in long-established democracies, by arguing that movements may also contribute to the consolidation of the democratic system itself. Moreover, scholarship on the consequences of social movements debates different mechanisms underlying the effectiveness of social movements, such as the broader political context (Amenta et al. 2005), framing (Cress and Snow 2000), and organization (Andrews 2004). The case studies in this analysis highlight the importance of organizational infrastructure and sides with other work that highlights mobilizing structures of social movements. At its broadest, this article contributes to a classic debate in the study of politics and society: political struggle does not handicap new democracies, as the elitist approach suggests, but contributes to their solidity.

\section{Acknowledgments}

I would like to thank Kenneth Andrews, Chris Bail, Shawn Bauldry, Ben Bradlow, Shane Elliott, Brandon Gorman, Ricarda Hammer, Ahsan Kamal, Charles Kurzman, Char Lloyd, David S. Meyer, Andrew Perrin, David Rigby, Graeme Robertson, Charles Seguin, and Adaner Umani for their help and comments. I also thank the $A S R$ editors and four anonymous reviewers for their constructive feedback.

\section{Notes}

1. Formal organizations have established procedures and structures to perform certain tasks routinely despite changes in leadership. They also have procedures for decision-making and the division of labor between units, with various tasks for different branches, some criteria for membership, and rules for lower-level units (Staggenborg 1988).

2. Some studies suggest that informal networks are more effective in mobilizing masses in repressive contexts, because it is harder for the government to target such networks. These studies mostly focus on shorter episodes of contention rather than prolonged mobilization campaigns (e.g., Opp and Gern 1993). Although these networks might survive a wave of repression, they still lack the capacity to evolve into sustained mobilization. Osa (2003), for example, in her analysis of the Solidarity movement in Poland, demonstrates that it was the formation of interconnected formal organizations within the movement that enabled Solidarity to survive Communist repression.

3. Geddes and colleagues (2014) also present a narrative about the beginning and end of each political regime that provides the rationale for the coding.

4. Ghana 1956 to 1960, Tanzania 1960 to 1964, and Laos 1960 to 1962.

5. I did not find many instances of disagreement about the beginning of movements. In the rare cases that did have disagreement, I looked at further sources and considered the argument presented in each source for counting the episode of contention as an important event.

6. See this and other supplementary materials at author's website: www.mohammadalikadivar.com. 
7. In a parliamentary system, the legislature elects the chief executive. In presidential systems, the president is elected by direct or electoral college. Mixed systems combine the features of these two systems - for example, when a president and prime minister divide the executive power. For more details on coding rules, see

http://siteresources.worldbank.org/INTRES/Resources/4692321107449512766/DPI2012 Codebook2.pdf.

8. I also explored accounting for the nested structure of the data using a Cox model with random effects (a shared-frailty model). The model was numerically unstable, however, and introduced additional assumptions concerning the independence of the frailty and the covariates, so I ultimately decided to address the nested structure through cluster-robust standard errors.

9. This difference in ratio is not statistically significant, which is consistent with my hypothesis (and the regression results presented later) that it is the duration of the campaign, not just its mere occurrence, that matters.

10. I explored the possibility that the effect of mobilization length on democratic survival might not be linear, but results show that linear specification is correct.

11. All robustness results are available from the author upon request.

12. In addition to this case study, I also examined the formation of new actors from the prodemocracy movement and their subsequent role in the transition in all cases of democratization with an unarmed mobilization of four years or longer (18 cases). Corresponding with my theory, I found that in all but two or three cases, new political actors emerged from anti-authoritarian mobilization that exerted significant influence in the transition process.

13. Democracy in South Africa has survived despite the weakness of internal democracy within the ANC. The ANC has been criticized for not tolerating internal dissidence within its ranks. To sustain armed struggle against the repressive apartheid regime, the ANC borrowed principles of "democratic centralism" from the SACP during their long cooperation, emphasizing a centralist and hierarchical organizational ethos. This organizational ethos was different from the UDF's and COSATU's more democratic and decentralized leadership within the country. However, as the exiled leadership replaced and dominated the internal leadership, its hierarchical ethos severely limited democracy within the ANC party structure in the post-transition period, and thus it constrained the quality of democracy in South Africa (Butler 2003; Lotshwao 2009; McKinley 2001). As discussed earlier, opposition organizations are more likely to show oligarchic tendencies after a transition. This tendency could be observed in the ANC's lack of internal democracy after the transition. On the other hand, the ANC's centralism has not been unchallenged, and multiple splits have occurred within the party.

14. Moreover, the labor movement after the transition is not limited to COSATU. COSATU's close partnership with the ANC, and the ANC's implementation of neoliberal programs, have generated opposition within labor unions. Such opposition has resulted in the formation of the South African Federation of Trade Unions (SAFTU). Holding that the ANC has not delivered on the promises of the struggle to improve the lives of ordinary workers, SAFTU sees its mandate as battling corruption and the erosion of democracy. With 7,300 members, SAFTU is the second largest union in the country (Luckett and Munshi 2017).

15. As Heller (2009) points out, the ANC's organizational strength and hegemonic position, which once helped stabilize and consolidate electoral democracy in South Africa, has also operated as an impediment to deepening democracy and has even eroded democratic quality in important aspects. 
16. South Africa is an exceptional case where we observe both armed and unarmed campaigns. Importantly, as was discussed earlier, it was the political crisis created by the nonviolent campaign that triggered the democratic transition. In terms of the effects of the violent and nonviolent methods on democratic longevity, we can draw some conclusions from this case. The formation and linkage of organizations such as COSATU and SANCO were the result of the unarmed campaign, as these were organizations involved in unarmed methods of protest. For the ANC, however, it would be difficult to make a distinction between the effects of armed and unarmed methods, as the ANC used both tactics. In addition, many unarmed activists inside the country formally joined the ANC after the dissolution of the UDF. In terms of vibrancy of civil society and popularity of methods of protest, again the credit should be given to methods of nonviolent action.

\section{References}

<AUTHOR: Please make sure references include authors' middle initials and articles' subtitles, where appropriate.>

Adler, Glenn, and Eddie Webster. 1995. "Challenging Transition Theory: The Labor Movement, Radical Reform, and Transition to Democracy in South Africa." Politics \& Society 23(1):75-106.

Adler, Glenn, and Eddie Webster. 2000. "Introduction: Consolidating Democracy in a Liberalizing World: Trade Unions and Democratization in South Africa." Pp. 1-19 in Trade Unions and Democratization in South Africa, 1985-1997, edited by E. Webster and G. Adler. London, UK: McMillan Press.

Alemán, José, and David D. Yang. 2011. "A Duration Analysis of Democratic Transitions and Authoritarian Backslides." Comparative Political Studies 44(9):1123-51.

Almeida, Paul D. 2003. "Opportunity Organizations and Threat-Induced Contention: Protest Waves in Authoritarian Settings." American Journal of Sociology 109(2):345-400.

Amenta, Edwin, Neal Caren, Elizabeth Chiarello, and Yang Su. 2010. "The Political Consequences of Social Movements." Annual Review of Sociology 36:287-307.

Amenta, Edwin, Neal Caren, and Sheera Joy Olasky. 2005. "Age for Leisure? Political Mediation and the Impact of the Pension Movement on U.S. Old-Age Policy." American Sociological Review 70(3):516-38.

Andrews, Kenneth T. 2001. "Social Movements and Policy Implementation: The Mississippi Civil Rights Movement and the War on Poverty, 1965 to 1971." American Sociological Review 66(1):71-95.

Andrews, Kenneth T. 2004. Freedom Is a Constant Struggle: The Mississippi Civil Rights Movement and Its Legacy. Chicago: University of Chicago Press.

Banks, Arthur S., and Kenneth A. Wilson. 2013. Cross-National Time-Series Data Archive. Jerusalem, Israel: Databanks International.

Beck, Thorsten, George Clarke, Alberto Groff, Philip Keefer, and Patrick Walsh. 2001. "New Tools in Comparative Political Economy: The Database of Political Institutions." World Bank Economic Review 15(1):165-76. 
Beissinger, Mark R. 2002. Nationalist Mobilization and the Collapse of the Soviet State. Cambridge, UK: Cambridge University Press.

Beissinger, Mark R. 2013. "The Semblance of Democratic Revolution: Coalitions in Ukraine's Orange Revolution.” American Political Science Review 107(3):574-92.

Beissinger, Mark R. 2017. “'Conventional' and 'Virtual' Civil Societies in Autocratic Regimes." Comparative Politics 49(3):351-71.

Belloni, Roberto. 2008. "Civil Society in War-to-Democracy Transitions." Pp. 182-210 in From War to Democracy: Dilemmas of Peacebuilding, edited by A. K. Jarstad and T. D. Sisk. Cambridge, UK: Cambridge University Press.

Berman, Sheri. 1997. "Civil Society and the Collapse of the Weimar Republic." World Politics 49(3):401-429.

Bernhard, Michael, Timothy Nordstrom, and Christopher Reenock. 2001. "Economic Performance, Institutional Intermediation, and Democratic Survival." Journal of Politics 63(3):775-803.

Bob, Clifford. 2005. The Marketing of Rebellion: Insurgents, Media, and International Activism. Cambridge, UK: Cambridge Ubiversity Press.

Boix, Carles. 2011. "Democracy, Development, and the International System." American Political Science Review 105(4):809-828.

Bratton, Michael, and Nicholas Van de Walle. 1997. Democratic Experiments in Africa: Regime Transitions in Comparative Perspective. Cambridge, UK: Cambridge University Press.

Buhlungu, Sakhela. 2010. A Paradox of Victory: COSATU and the Democratic Transformation in South Africa. Scottsville, South Africa: University Of KwaZulu-Natal Press.

Butler, Anthony. 2003. "South Africa's Political Futures." Government and Opposition 38(1):93-112.

Butler, Anthony. 2005. "How Democratic Is the African National Congress?" Journal of Southern African Studies 31(4):719-36.

Caren, Neal, Sarah Gaby, and Catherine Herrold. 2017. "Economic Breakdown and Collective Action." Social Problems 64(1):133-55.

Celestino, Mauricio Rivera, and Kristian Skrede Gleditsch. 2013. "Fresh Carnations or All Thorn, No Rose? Nonviolent Campaigns and Transitions in Autocracies." Journal of Peace Research 50(3):385-400.

Chang, Paul. 2015. Protest Dialectics: State Repression and South Korea's Democracy Movement, 1970-1979. Stanford, CA: Stanford University Press.

Cheibub, José Antonio, Jennifer Gandhi, and James Raymond Vreeland. 2010. "Democracy and Dictatorship Revisited." Public Choice 143(1-2):67-101. 
Chenoweth, Erica, and Kathleen Gallagher Cunningham. 2013. "Understanding Nonviolent Resistance: An Introduction." Journal of Peace Research 50(3):271-76.

Chenoweth, Erica, and Maria J. Stephan. 2012. Why Civil Resistance Works: The Strategic Logic of Nonviolent Conflict, reprint. New York: Columbia University Press.

Cox, David R. 1972. "Regression Models and Life-Tables.” Journal of the Royal Statistical Society. Series B (Methodological) 34(2):187-220.

Cox, David Roxbee, and David Oakes. 1984. Analysis of Survival Data. London: Chapman \& Hall/CRC.

Cress, Daniel M., and David A. Snow. 2000. "The Outcomes of Homeless Mobilization: The Influence of Organization, Disruption, Political Mediation, and Framing." American Journal of Sociology 105(4):1063-1104.

Desai, Manali. 2001. "Party Formation, Political Power, and the Capacity for Reform: Comparing Left Parties in Kerala and West Bengal, India.” Social Forces 80(1):37-60.

Diamond, Larry Jay. 1999. Developing Democracy: Toward Consolidation. Baltimore, MD: Johns Hopkins University Press.

Diamond, Larry Jay. 2009. The Spirit of Democracy. New York: H. Holt.

Edwards, Bob, and John D. McCarthy. 2004. "Resources and Social Movement Mobilization." Pp. 116-52 in The Blackwell Companion to Social Movements, edited by D. A. Snow, S. A. Soule, and H. Kriesi. Malden, MA: Blackwell Publishing Ltd.

Ekiert, Grzegorz, and Jan Kubik. 1999. Rebellious Civil Society: Popular Protest and Democratic Consolidation in Poland, 1989-1993. Ann Arbor: The University of Michigan Press.

Ekiert, Grzegorz, Jan Kubik, and Milada Anna Vachudova. 2007. "Democracy in the PostCommunist World: An Unending Quest?” East European Politics \& Societies 21(1):7-30.

Ermakoff, Ivan. 2008. Ruling Oneself Out: A Theory of Collective Abdications. Durham, NC: Duke University Press Books.

Fishman, Robert M. 2011. "Democratic Practice after the Revolution: The Case of Portugal and Beyond." Politics \& Society 39(2):233-67.

Friedman, Steven. 2012. "Beyond the Fringe? South African Social Movements and the Politics of Redistribution.” Review of African Political Economy 39(131):85-100.

Fung, Archon. 2003. "Associations and Democracy: Between Theories, Hopes, and Realities." Annual Review of Sociology 29(1):515-39.

Ganz, Marshall. 2010. Why David Sometimes Wins: Leadership, Organization, and Strategy in the California Farm Worker Movement, reprint ed. Oxford, UK: Oxford University Press.

Geddes, Barbara, Joseph Wright, and Erica Frantz. 2014. "Autocratic Breakdown and Regime Transitions: A New Data Set.” Perspectives on Politics 12(2):313-31. 
Gerring, John. 2006. Case Study Research: Principles and Practices. Cambridge, UK: Cambridge University Press.

Giugni, Marco. 2007. "Useless Protest? A Time-Series Analysis of the Policy Outcomes of Ecology, Antinuclear, and Peace Movements in the United States, 1977-1995." Mobilization: An International Quarterly 12(1):53-77.

Goertz, Gary, and James Mahoney. 2012. A Tale of Two Cultures: Qualitative and Quantitative Research in the Social Sciences. Princeton, NJ: Princeton University Press.

Gramsci, Antonio. 1971. Selections from the Prison Notebooks. New York: International Publishers Co.

Grodsky, Brian K. 2012. Social Movements and the New State: The Fate of pro-Democracy Organizations When Democracy Is Won. Stanford, CA: Stanford University Press.

Haggard, Stephan, and Robert R. Kaufman. 2012. "Inequality and Regime Change: Democratic Transitions and the Stability of Democratic Rule." American Political Science Review 106(3):495-516.

Haggard, Stephan, and Robert R. Kaufman. 2016. Dictators and Democrats: Masses, Elites, and Regime Change. Princeton, NJ: Princeton University Press.

Heller, Patrick. 2009. "Democratic Deepening in India and South Africa." Journal of Asian and African Studies 44(1):123-49.

Higley, John, and Michael G. Burton. 1989. "The Elite Variable in Democratic Transitions and Breakdowns." American Sociological Review 54(1):17-32.

Howard, Marc Morjé, and Meir R. Walters. 2015. "Mass Mobilization and the Democracy Bias." Middle East Policy 22(2):145-55.

Huang, Reyko. 2016. The Wartime Origins of Democratization: Civil War, Rebel Governance, and Political Regimes. New York: Cambridge University Press.

Huntington, Samuel P. 1984. “Will More Countries Become Democratic?” Political Science Quarterly 99(2):193-218.

Huntington, Samuel P. 1993. The Third Wave: Democratization in the Late 20th Century. Norman: University of Oklahoma Press.

Kadivar, Mohammad Ali, and Neal Caren. 2016. "Disruptive Democratization: Contentious Events and Liberalizing Outcomes Globally, 1990-2004.” Social Forces 94(3):975-96.

Kapstein, Ethan B., and Nathan Converse. 2008. The Fate of Young Democracies. Cambridge, UK: Cambridge University Press.

Karl, Terry Lynn. 1990. "Dilemmas of Democratization in Latin America." Comparative Politics 23(1):1-21.

van Kessel, Ineke. 2000. "Beyond Our Wildest Dreams": The United Democratic Front and the Transformation of South Africa. Charlottesville: University of Virginia Press. 
van Kessel, Ineke. 2009. “The United Democratic Front's Legacy in South Africa: Mission Accomplished or Vision Betrayed?” Pp. 197-220 in Movers and Shakers: Social Movements in Africa, edited by S. D. K. Ellis and I. van Kessel. Leiden, Netherlands: Brill.

Ketchley, Neil. 2017. Egypt in a Time of Revolution: Contentious Politics and the Arab Spring. S.1.: Cambridge University Press.

Klandermans, Bert. 2015. "Movement Politics and Party Politics in Times of Democratic Transition: South Africa, 1994-2000.” Pp. 241-58 in Movements in Times of Democratic Transition, edited by B. Klandermans and C. van Stralen. Philadelphia: Temple University Press.

Kovacs, Mimmi Söderberg. 2008. "When Rebels Change Their Stripes: Armed Insurgents in Post-War Politics.” Pp. 134-56 in From War to Democracy: Dilemmas of Peacebuilding, edited by A. K. Jarstad and T. D. Sisk. Cambridge, UK: Cambridge University Press.

Kurzman, Charles. 2004. The Unthinkable Revolution in Iran. Cambridge, MA: Harvard University Press.

Kurzman, Charles. 2008. Democracy Denied, 1905-1915: Intellectuals and the Fate of Democracy. Cambridge, MA: Harvard University Press.

Lee, Cheol-Sung. 2016. “Going Underground: The Origins of Divergent Forms of Labor Parties in Recently Democratized Countries.” Sociological Theory 34(3):220-49.

Lehoucq, Fabrice. 2016. “Does Nonviolence Work?” Comparative Politics 48(2):269-87.

Levitsky, Steven, and Lucan Way. 2013. “The Durability of Revolutionary Regimes.” Journal of Democracy 24(3):5-17.

Linz, Juan José, and Alfred C. Stepan. 1978. The Breakdown of Democratic Regimes, Latin America. Baltimore, MD: Johns Hopkins University Press.

Linz, Juan José, and Alfred C. Stepan. 1996. Problems of Democratic Transition and Consolidation: Southern Europe, South America, and Post-Communist Europe. Baltimore, MD: Johns Hopkins University Press.

Lipset, Seymour Martin. 1994. "The Social Requisites of Democracy Revisited: 1993 Presidential Address.” American Sociological Review 59(1):1-22.

Lotshwao, Kebapetse. 2009. "The Lack of Internal Party Democracy in the African National Congress: A Threat to the Consolidation of Democracy in South Africa." Journal of Southern African Studies 35(4):901-914.

Loveman, Mara. 1998. "High-Risk Collective Action: Defending Human Rights in Chile, Uruguay, and Argentina.” American Journal of Sociology 104(2):477-525.

Luckett, Thembi and Naadira Munshi. 2017. "Rebuilding a Workers' Movement.” Jacobin. Retrieved July 3, 2017 (http://jacobinmag.com/2017/05/south-africa-trade-unions-saftu-numsaanc-zuma).

Mahoney, James. 1999. "Nominal, Ordinal, and Narrative Appraisal in Macrocausal Analysis." American Journal of Sociology 104(4):1154-96. 
Mainwaring, Scott, and Aníbal Pérez-Liñán. 2013. "Democratic Breakdown and Survival." Journal of Democracy 24(2):123-37.

Marx, Anthony W. 1992. Lessons of Struggle: South African Internal Opposition, 1960-1990. New York: Oxford University Press.

Marx, Karl. [1852] 1994. The Eighteenth Brumaire of Louis Bonaparte. New York: International Publishers.

McAdam, Doug. 1999. Political Process and the Development of Black Insurgency, 1930-1970, 2nd ed. Chicago: The University of Chicago Press.

McAdam, Doug, Sidney G. Tarrow, and Charles Tilly. 2001. Dynamics of Contention . Cambridge, UK: Cambridge University Press.

McCammon, Holly J., Soma Chaudhuri, Lyndi Hewitt, Courtney Sanders Muse, Harmony D. Newman, Carrie Lee Smith, and Teresa M. Terrell. 2008. "Becoming Full Citizens: The U.S. Women's Jury Rights Campaigns, the Pace of Reform, and Strategic Adaptation." American Journal of Sociology 113(4):1104-47.

McFaul, Michael. 2002. "The Fourth Wave of Democracy and Dictatorship: Noncooperative Transitions in the Postcommunist World." World Politics 54(2):212-44.

McKinley, Dale T. 1997. The ANC and the Liberation Struggle: A Critical Political Biography, first paperback ed. London, UK: Pluto Press.

McKinley, Dale T. 2001. "Democracy, Power and Patronage: Debate and Opposition within the African National Congress and the Tripartite Alliance since 1994." Democratization 8(1):183206

Meyer, David S. 2004. "Protest and Political Opportunities." Annual Review of Sociology 30:125-45.

Moore, Barrington, Jr. 1966. Social Origins of Dictatorship and Democracy: Lord and Peasant in the Making of the Modern World. Boston, MA: Beacon Press.

Morris, Aldon D., and Suzanne Staggenborg. 2004. "Leadership in Social Movements." Pp. 171-96 in The Blackwell Companion to Social Movements, edited by D. A. Snow, S. A. Soule, and H. Kriesi. Malden, MA: Blackwell Publishing Ltd.

Munck, Gerardo L., and Carol Skalnik Leff. 1997. "Modes of Transition and Democratization: South America and Eastern Europe in Comparative Perspective." Comparative Politics 29(3):343-62.

Nepstad, Sharon Erickson. 2011. Nonviolent Revolutions: Civil Resistance in the Late 20th Century. New York: Oxford University Press.

O’Donnell, Guillermo, and Philippe C. Schmitter. 1986. Transitions from Authoritarian Rule, Vol. 4, Tentative Conclusions about Uncertain Democracies. Baltimore, MD: The Johns Hopkins University Press. 
Oliver, Pamela. 1989. "Bringing the Crowd Back In: The Nonorganizational Elements of Social Movements." Research in Social Movements, Conflict and Change 11:1-30.

Opp, Karl-Dieter, and Christiane Gern. 1993. "Dissident Groups, Personal Networks, and Spontaneous Cooperation: The East German Revolution of 1989." American Sociological Review 58(5):659-80.

Osa, Maryjane. 2003. Solidarity and Contention: Networks of Polish Opposition. Minneapolis: University of Minnesota Press.

Piven, Frances Fox, and Richard Cloward. 1979. Poor People's Movements: Why They Succeed, How They Fail. New York: Vintage.

Przeworski, Adam, and Fernando Limongi. 1997. "Modernization: Theories and Facts." World Politics 49(2):155-83.

Putnam, Robert D. 2001. Bowling Alone: The Collapse and Revival of American Community. New York: Touchstone Books by Simon \& Schuster.

Ragin, Charles C. 1989. The Comparative Method: Moving Beyond Qualitative and Quantitative Strategies. Berkeley: University of California Press.

Riley, Dylan. 2010. The Civic Foundations of Fascism in Europe: Italy, Spain, and Romania, 1870-1945. Baltimore, MD: Johns Hopkins University Press.

Robins, Steven, and Christopher J. Colvin. 2015. "Social Movements After Apartheid: Rethinking Strategies and Tactics in a Time of Democratic Transition." Pp. 259-280 in Movements in Times of Democratic Transition, edited by B. Klandermans and C. van Stralen. Philadelphia: Temple University Press.

Ross, Michael L. 2012. The Oil Curse: How Petroleum Wealth Shapes the Development of Nations. Princeton, NJ: Princeton University Press.

Rueschemeyer, Dietrich, Evelyne Huber Stephens, and John D. Stephens. 1992. Capitalist Development and Democracy. Chicago: University Of Chicago Press.

Runciman, Carin. 2016. "The 'Ballot and the Brick': Protest, Voting and Non-Voting in PostApartheid South Africa." Journal of Contemporary African Studies 34(4):419-36.

Schock, Kurt. 2005. Unarmed Insurrections: People Power Movements in Nondemocracies. Minneapolis: University of Minnesota Press.

Seekings, Jeremy. 2000. The UDF: A History of the United Democratic Front in South Africa 1983-1991. Athens: Ohio University Press.

Seidman, Gay W. 1994. Manufacturing Militance: Workers' Movements in Brazil and South Africa, 1970-1985. Berkeley: University of California Press.

Sinwell, Luke. 2011. "Rethinking South Africa's Transition: From Transformative to Mainstream Approaches to Participatory Development." African Studies 70(3):359-75.

Skocpol, Theda. 1979. States and Social Revolutions: A Comparative Analysis of France, Russia, and China. Cambridge, UK: Cambridge University Press. 
Skocpol, Theda. 2003. Diminished Democracy: From Membership to Management in American Civic Life. Norman: University of Oklahoma Press.

Smith, Benjamin. 2004. "Oil Wealth and Regime Survival in the Developing World, 19601999.” American Journal of Political Science 48(2):232-46.

Staggenborg, Suzanne. 1988. "The Consequences of Professionalization and Formalization in the Pro-Choice Movement.” American Sociological Review 53(4):585-605.

Stephan, Maria J., and Erica Chenoweth. 2008. "Why Civil Resistance Works: The Strategic Logic of Nonviolent Conflict." International Security 33(1):7-44.

Svolik, Milan. 2008. “Authoritarian Reversals and Democratic Consolidation.” American Political Science Review 102(2):153-68.

Tilly, Charles. 1995. "Democracy Is a Lake.” Pp. 365-87 in The Social Construction of Democracy, 1870-1990, edited by G. Andrews and H. Chapman. New York: New York University Press.

Tilly, Charles. 2003. Contention and Democracy in Europe, 1650-2000. Cambridge, UK: Cambridge University Press.

Tilly, Charles and Sidney Tarrow. 2015. Contentious Politics. 2 edition. New York, NY: Oxford University Press.

Tocqueville, Alexis de. [1835] 2002. Democracy in America. Chicago: University of Chicago Press.

Tufekci, Zeynep. 2017. Twitter and Tear Gas: The Power and Fragility of Networked Protest. New Haven, CT: Yale University Press.

Viterna, Jocelyn, and Kathleen M. Fallon. 2008. "Democratization, Women's Movements, and Gender-Equitable States: A Framework for Comparison.” American Sociological Review 73(4):668-89.

Webster, Edward, and Sakhela Buhlungu. 2004. "Between Marginalisation \& Revitalisation? The State of Trade Unionism in South Africa." Review of African Political Economy 31(100):229-45.

Wejnert, Barbara. 2005. "Diffusion, Development, and Democracy, 1800-1999." American Sociological Review 70(1):53-81.

Wimmer, Andreas, Lars-Erik Cederman, and Brian Min. 2009. "Ethnic Politics and Armed Conflict: A Configurational Analysis of a New Global Data Set." American Sociological Review 74(2):316-37.

Wood, Elisabeth Jean. 2000. Forging Democracy from Below: Insurgent Transitions in South Africa and El Salvador. Cambridge, UK: Cambridge University Press. 
Wood, Elisabeth Jean. 2001. "An Insurgent Path to Democracy: Popular Mobilization, Economic Interests, and Regime Transition in South Africa and El Salvador." Comparative Political Studies 34(8):862-88.

World Bank. 2012. World Development Indicators 2012. Washington, DC: World Bank.

Yarwood, Janette. 2016. “The Power of Protest.” Journal of Democracy 27(3):51-60.

Zuern, Elke. 2004. "Continuity in Contradiction?: The Prospects for a National Civic Movement in a Democratic State: SANCO and the ANC in Post-Apartheid South Africa." Retrieved

November 12, 2013

(http://ccs.ukzn.ac.za/files/Zuern\%20SANCO\%20Research\%20Report.pdf).

Mohammad Ali Kadivar is a postdoctoral fellow at Watson Institute for International and Public Affairs at Brown University.

Table 1. List of Democracies and Unarmed Mobilization Duration

\begin{tabular}{|c|c|c|c|c|c|}
\hline Country & $\begin{array}{l}\text { Years in the } \\
\text { Analysis }\end{array}$ & $\begin{array}{c}\text { Unarmed } \\
\text { Campaign } \\
\text { Length }\end{array}$ & Country & $\begin{array}{c}\text { Years in the } \\
\text { Analysis }\end{array}$ & $\begin{array}{c}\text { Unarmed } \\
\text { Campaign } \\
\text { Length }\end{array}$ \\
\hline Albania & $1992-2010$ & 3 & Mexico & $2001-2010$ & 0 \\
\hline Argentina & 1974-1976 & 1 & Moldova & 1992-2010 & 1 \\
\hline Argentina & 1984-2010 & 7 & Mongolia & 1994-2010 & 1 \\
\hline Armenia & 1992-1994 & 4 & Montenegro & 2007-2010 & 0 \\
\hline Azerbaijan & 1993-1993 & 3 & Myanmar & 1961-1962 & 0 \\
\hline Bangladesh & 1991-2007 & 3 & Nepal & 1992-2002 & 1 \\
\hline Bangladesh & 2009-2010 & 0 & Nepal & 2007-2010 & 3 \\
\hline Benin & 1992-2010 & 1 & Nicaragua & 1991-2010 & 0 \\
\hline Bolivia & 1983-2010 & 8 & Niger & 1994-1996 & 2 \\
\hline Brazil & 1986-2010 & 6 & Niger & 2000-2010 & 3 \\
\hline Bulgaria & 1991-2010 & 2 & Nigeria & 1961-1966 & 2 \\
\hline Burundi & 1994-1996 & 0 & Nigeria & 1980-1983 & 0 \\
\hline Burundi & 2006-2010 & 0 & Nigeria & 2000-2010 & 3 \\
\hline Cen African Rep & 1994-2003 & 0 & Pakistan & $1972-1975$ & 3 \\
\hline Chile & 1990-2010 & 6 & Pakistan & 1989-1999 & 0 \\
\hline Colombia & 1959-2010 & 1 & Pakistan & 2009-2010 & 1 \\
\hline Congo-Brz & 1993-1997 & 1 & Panama & $1956-1968$ & 0 \\
\hline
\end{tabular}




\begin{tabular}{|c|c|c|c|c|c|}
\hline Croatia & $1992-2010$ & 0 & Panama & $1990-2010$ & 0 \\
\hline Czechoslovakia & 1990-1993 & 1 & Paraguay & 1994-2010 & 0 \\
\hline Dominican Rep. & $1963-1963$ & 0 & Peru & 1957-1962 & 0 \\
\hline Dominican Rep. & 1979-2010 & 0 & Peru & 1964-1968 & 0 \\
\hline Ecuador & 1969-1970 & 1 & Peru & 1981-1992 & 3 \\
\hline Ecuador & 1980-2010 & 0 & Peru & 2002-2010 & 1 \\
\hline El Salvador & $1995-2010$ & 0 & Philippines & 1987-2010 & 4 \\
\hline Estonia & 1992-2010 & 5 & Poland & 1990-2010 & 6 \\
\hline Georgia & 2005-2010 & 2 & Portugal & 1977-2010 & 3 \\
\hline Ghana & $1970-1972$ & 0 & Romania & 1991-2010 & 2 \\
\hline Ghana & 1980-1981 & 2 & Russia & 1992-1993 & 5 \\
\hline Ghana & $2001-2010$ & 0 & Senegal & 2001-2010 & 0 \\
\hline Greece & $1975-2010$ & 1 & Serbia & 2001-2010 & 4 \\
\hline Guatemala & 1996-2010 & 1 & Sierra Leone & $1962-1967$ & 3 \\
\hline Guinea Bissau & 2001-2002 & 0 & Sierra Leone & 1997-1997 & 0 \\
\hline Guinea Bissau & 2006-2010 & 0 & Sierra Leone & 1999-2010 & 0 \\
\hline Haiti & 1991-1991 & 4 & Slovakia & 1993-2010 & 3 \\
\hline Haiti & 1995-1999 & 0 & Slovenia & 1992-2010 & 0 \\
\hline Haiti & 2007-2010 & 0 & Somalia & 1961-1969 & 5 \\
\hline Honduras & $1958-1963$ & 0 & South Africa & 1995-2010 & 13 \\
\hline Honduras & $1972-1972$ & 0 & Spain & $1978-2010$ & 6 \\
\hline Honduras & $1982-2010$ & 0 & Sri Lanka & 1995-2010 & 0 \\
\hline Hungary & 1991-2010 & 0 & Sudan & 1966-1969 & 1 \\
\hline Indonesia & 2000-2010 & 2 & Sudan & 1987-1989 & 1 \\
\hline Kenya & 2003-2010 & 2 & Syria & $1962-1962$ & 0 \\
\hline Korea South & 1961-1961 & 1 & Taiwan & 2001-2010 & 0 \\
\hline Korea South & 1988-2010 & 2 & Thailand & 1976-1976 & 1 \\
\hline Latvia & 1992-2010 & 5 & Thailand & 1989-1991 & 0 \\
\hline
\end{tabular}




\begin{tabular}{|c|c|c|c|c|c|}
\hline Lebanon & $2006-2010$ & 1 & Thailand & $1993-2006$ & 1 \\
\hline Lesotho & 1966-1970 & 0 & Thailand & 2008-2010 & 1 \\
\hline Lesotho & 1994-2010 & 1 & Togo & 1964-1967 & 0 \\
\hline Liberia & 2006-2010 & 0 & Turkey & $1962-1980$ & 0 \\
\hline Lithuania & 1992-2010 & 4 & Turkey & 1984-2010 & 0 \\
\hline Macedonia & 1992-2010 & 0 & Uganda & 1963-1966 & 0 \\
\hline Madagascar & 1994-2009 & 2 & Ukraine & 1992-2010 & 4 \\
\hline Malawi & 1995-2010 & 1 & Uruguay & 1985-2010 & 2 \\
\hline Mali & 1993-2010 & 2 & Venezuela & 1959-2005 & 1 \\
\hline Mauritania & 2008-2008 & 0 & Zambia & 1965-1967 & 3 \\
\hline Mauritius & 1969-2010 & 0 & Zambia & 1992-1996 & 1 \\
\hline Mexico & $2001-2010$ & 0 & & & \\
\hline
\end{tabular}




\begin{tabular}{|c|c|c|c|c|c|c|c|}
\hline Variable & Mean & Median & $\mathrm{p} 5$ & p95 & $\mathrm{sd}$ & $\overline{\text { sd_w }}$ & sd_b \\
\hline Post-Military & .4069767 & 0 & 0 & 1 & .4914386 & .1715665 & .4404555 \\
\hline Post-Personal & .3618331 & 0 & 0 & 1 & .4806953 & .1600177 & .4458784 \\
\hline Post-Party & .2202462 & 0 & 0 & 1 & .4145544 & .0862715 & .4383276 \\
\hline Post-Independence & .2004104 & 0 & 0 & 1 & .4004444 & .1268194 & .4081424 \\
\hline Presidential & .5889193 & 1 & 0 & 1 & .4921982 & .1861656 & .4510386 \\
\hline Mixed System & .1046512 & 0 & 0 & 1 & .3062082 & .2031993 & .2786371 \\
\hline Democracies in the Region & .5458537 & .5909091 & .0526316 & .8947368 & .29319 & .1353369 & .280838 \\
\hline Ethnic Fractionalization & .3579464 & .2744 & .0056763 & .803757 & .2672268 & .0071532 & .2787032 \\
\hline Excluded Population & .1319881 & .07 & 0 & .45 & .1586302 & .0623397 & .1498777 \\
\hline Past Democratic Experience & 4.73119 & 2 & 0 & 15 & 5.955767 & 2.469064 & 5.42005 \\
\hline Oil Production per Capita & 1.996339 & 1.125203 & 0 & 6.311915 & 2.294149 & .6684698 & 2.158207 \\
\hline GDP per Capita (ln) & 7.500975609 & 7.580627441 & 5.401501656 & 9.338500023 & 1.247751474 & .319135278 & 1.289705157 \\
\hline GDP Growth & .0191804 & .0244032 & -.0724313 & .0839445 & .0553168 & .0517231 & .0450874 \\
\hline Population (ln) & 16.22705 & 16.13902 & 14.12714 & 18.52889 & 1.276685 & .2201078 & 1.294279 \\
\hline
\end{tabular}


Table 3. Contentious Transition Legacy and Democratic Breakdown

\begin{tabular}{|c|c|c|c|c|}
\hline & (1) & (2) & (3) & (4) \\
\hline \multirow[t]{2}{*}{ Nonviolent Campaign Duration } & $-.200 *$ & $-.198^{*}$ & $-.225^{*}$ & \\
\hline & $(.0864)$ & $(.0779)$ & $(.107)$ & \\
\hline \multirow[t]{2}{*}{ Nonviolent Campaign at Transition } & & & & -.536 \\
\hline & & & & $(.306)$ \\
\hline \multirow[t]{2}{*}{ Oil Production per Capita (ln) } & & .0400 & .0779 & .0510 \\
\hline & & $(.0820)$ & $(.119)$ & $(.0880)$ \\
\hline \multirow[t]{2}{*}{ Post-Military } & & $1.006^{*}$ & 1.207 & $1.038^{*}$ \\
\hline & & $(.459)$ & $(.703)$ & $(.450)$ \\
\hline \multirow[t]{2}{*}{ Post-Personal } & & .375 & -.742 & .449 \\
\hline & & $(.425)$ & $(.620)$ & $(.422)$ \\
\hline \multirow[t]{2}{*}{ Post-Party } & & .534 & .237 & .623 \\
\hline & & $(.580)$ & $(.611)$ & $(.562)$ \\
\hline \multirow[t]{2}{*}{ Post-Independence } & & .649 & 1.007 & .615 \\
\hline & & $(.650)$ & $(.699)$ & $(.614)$ \\
\hline \multirow[t]{2}{*}{ Presidential } & & .266 & .811 & .257 \\
\hline & & $(.534)$ & $(.740)$ & $(.569)$ \\
\hline \multirow[t]{2}{*}{ Mixed System } & & $1.848 * *$ & $1.856^{*}$ & $1.784 * *$ \\
\hline & & $(.475)$ & $(.923)$ & $(.517)$ \\
\hline \multirow[t]{2}{*}{ Democracies in the Region } & & $-2.413^{* *}$ & $-2.227^{*}$ & $-2.628 * *$ \\
\hline & & $(.797)$ & $(.976)$ & $(.817)$ \\
\hline \multirow[t]{2}{*}{ Ethnic Fractionalization } & & .0856 & -.922 & .0104 \\
\hline & & $(.634)$ & $(.944)$ & $(.611)$ \\
\hline \multirow[t]{2}{*}{ Excluded Population } & & .675 & -.200 & .811 \\
\hline & & $(.603)$ & $(.938)$ & $(.700)$ \\
\hline \multirow[t]{2}{*}{ GDP per Capita (ln) } & $-.488 * *$ & $-.345^{*}$ & $-.727^{*}$ & $-.392 *$ \\
\hline & $(.117)$ & $(.172)$ & $(.302)$ & $(.162)$ \\
\hline \multirow[t]{2}{*}{ GDP Growth } & $-4.823^{*}$ & -3.964 & -3.584 & -3.432 \\
\hline & $(2.422)$ & $(2.932)$ & $(2.921)$ & $(2.921)$ \\
\hline
\end{tabular}




\begin{tabular}{|c|c|c|c|c|}
\hline Population $(\ln )$ & .121 & .127 & .268 & .110 \\
\hline & $(.106)$ & $(.155)$ & $(.186)$ & $(.158)$ \\
\hline \multirow[t]{2}{*}{ Past Democratic Experience } & $-.0404 *$ & $-.0672 * *$ & -.0443 & $-.0651 * *$ \\
\hline & $(.0198)$ & $(.0238)$ & $(.0350)$ & $(.0244)$ \\
\hline Failures & 48 & 48 & 26 & 48 \\
\hline Subjects & 112 & 111 & 65 & 111 \\
\hline Clusters & 80 & 79 & 54 & 79 \\
\hline Observations & 1,383 & 1,344 & 895 & 1,344 \\
\hline$A I C$ & 392.0 & 365.2 & 189.3 & 367.4 \\
\hline$B I C$ & 418.1 & 443.3 & 261.3 & 445.4 \\
\hline
\end{tabular}

Note: Standard errors are in parentheses.

${ }^{*} p<.05 ;{ }^{* *} p<.01<$ AUTHOR: Are these one- or two-tailed? $>$ 


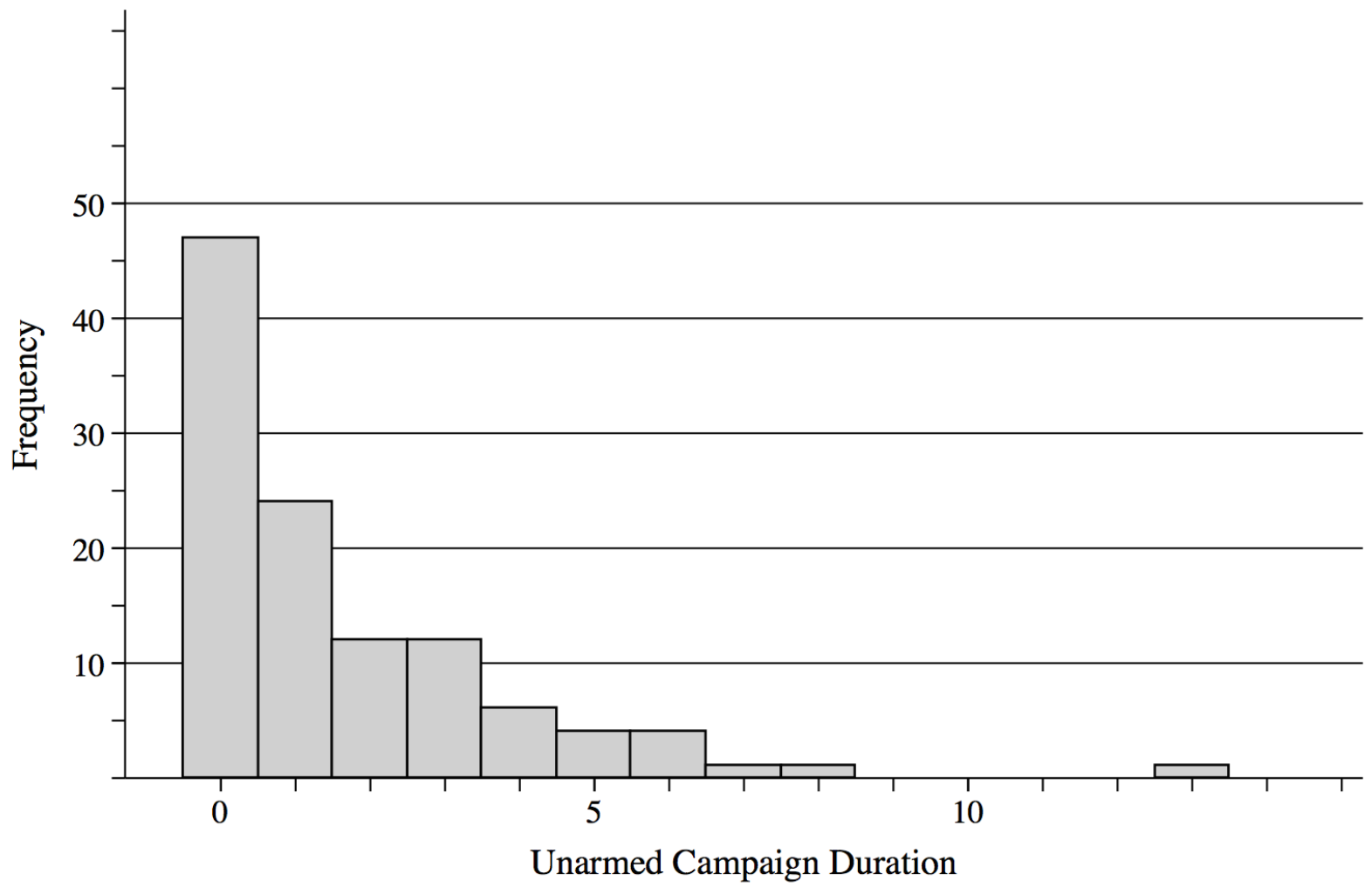

Figure 1. Frequency of Unarmed Campaign Durations in the Sample

\section{Cox Proportional Hazards Regression}

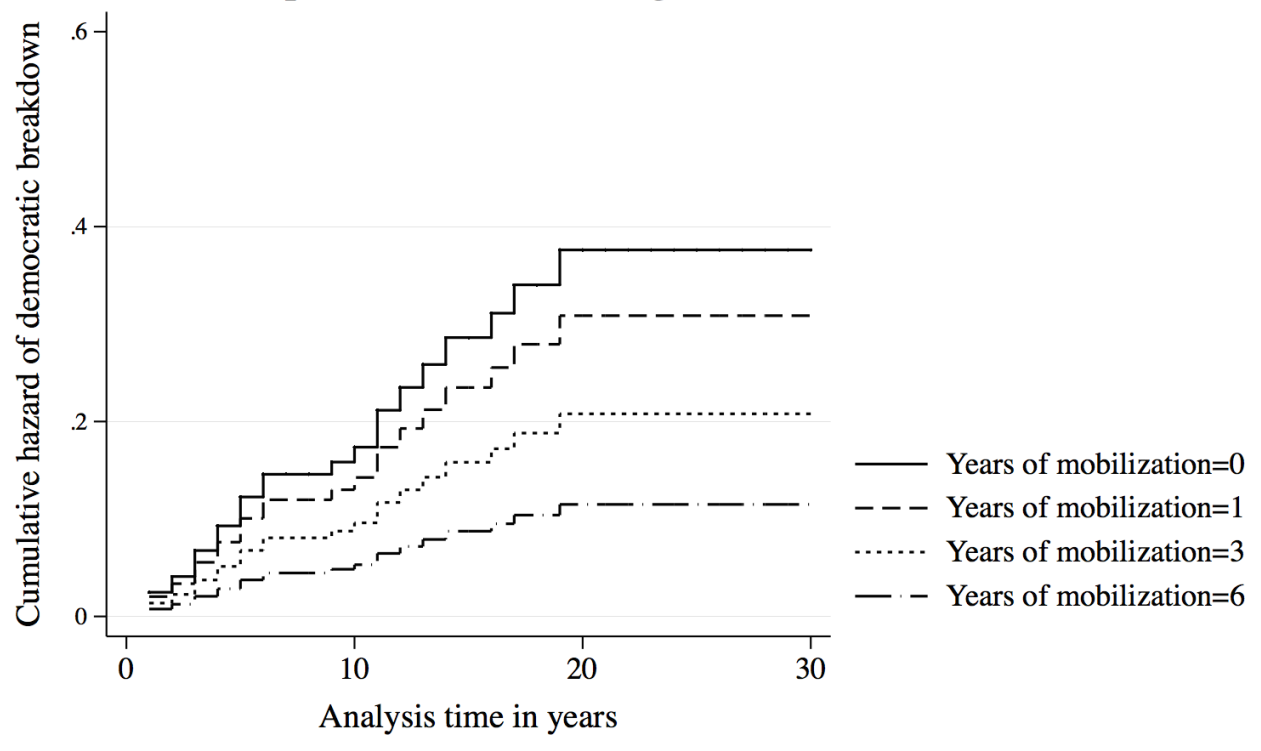

Based on Table 3, Model 2

Figure 2. Cumulative Hazard of Democratic Breakdown over Time for Democracies Emerging from Different Lengths of Mobilization 
